\title{
Cranberry products in the prevention of urinary tract infections: examining the evidence
}

This article was published in the following Dove Press journal:

Botanics: Targets and Therapy

14 July 2015

Number of times this article has been viewed

\author{
Rainer Nowack \\ Rainer Birck \\ Nephrology/Dialysis Clinic, \\ Lindau, Germany
}

Correspondence: Rainer Nowack Nephrology/Dialysis Clinic, Friedrichshafener Strasse 82, D-88I3 I Lindau, Germany Tel +4983822762100 Fax +498382 2762109 Email nowack@dialyse-lindau.de

\begin{abstract}
Cranberry (Vaccinium macrocarpon) juice and extracts are widely used and recommended as folk remedy for prophylaxis of urinary tract infections (UTIs). Its putative mechanism is an anti-adhesive effect that prevents docking of bacteria on host tissues. The antiadhesion quality is attributed to A-type proanthocyanidins (PACs), a group of polyphenols that has a restricted occurrence in cranberries and a few related plants. Clinical trials with cranberry have provided a mixed evidence on behalf of UTI prophylaxis. In some trials, a benefit could not be detected due to lower than calculated UTI recurrence rates, in others failure had retrospectively been blamed on underdosing of cranberry products. To circumvent such problems, cranberry products need to be standardized for the bioactive principle of PAC and administered at a sufficient dose. Further characterization of PAC bioavailability, improvement of the currently inconvenient prescriptions, and above all of the palatability for patients is strongly recommended. Larger staged trials should then be carried out in patients with relevant UTI risks.
\end{abstract}

Keywords: cranberry (Vaccinium macrocarpon Aiton), urinary tract infection, proanthocyanidins, anti-adhesion, p-fimbriae

\section{Introduction}

Dried fruits, juice, or extracts of the American cranberry (Vaccinium macrocarpon) have become increasingly popular in patients with recurrent urinary tract infections (UTIs). Physicians have adopted the folk remedy from the American Indians, and its presumed benefit has been scientifically explored since the 1950 s.

Laboratory research has suggested the interference of cranberry products with the adhesion of bacteria to host tissue, eg, the bladder mucosa, as a unique and hitherto unknown anti-infective mechanism. After some landmark clinical trials had shown cranberry juice or extracts to be effective for prophylaxis of UTI, subsequent trials with negative outcomes had rendered the current evidence debatable.

\section{Anti-adhesion effects as putative anti-infective mechanism}

Cranberry juice had at first been assumed to halt bacterial growth by acidifying the urine $^{1-3}$ or to harbor bactericidal/bacteriostatic compounds, ${ }^{4,5}$ but studies failed to support these concepts. Instead, a mainstream of research has been committed on characterizing the newly detected anti-adhesive properties of cranberry products. ${ }^{6,7}$

Adhesion of uropathogenic bacteria like Escherichia coli to the urinary tract mucosa is a prerequisite for the pathogenesis of UTI. Bacteria adhere by fimbriae exposing lectins complementary to surface-exposed carbohydrates on the host side tissue, ${ }^{8}$ and bacteria differ by the various types of fimbriae that bestow them with more or 
less virulence. Adhesion via type-1 fimbriae, ubiquitously expressed by E. coli, is inhibited in the presence of fructose in vitro (hence mannose-sensible fimbriae). More virulent E. coli causing pyelonephritis and complicated UTI typically bear p-fimbriae in addition to type-1 fimbriae. Adhesion of p-fimbriated $E$. coli with their specific lectins ${ }^{9-11}$ is not inhibitable by fructose or other low molecular carbohydrates (hence mannose-resistant fimbriae).

Cranberry juice or extracts, as well as urine harvested from humans or experimental animals after ingestion of cranberries, reduce the adhesion of E. coli and other uropathogenic species in biologically relevant models. ${ }^{6,7,12-14}$ The anti-adhesive properties of cranberries are effective against the ubiquitous and comparatively benign $E$. coli with type-1 fimbriae, as well as against p-fimbriated and antibioticresistant $E$. coli strains. ${ }^{14-16}$ Incubation of p-fimbriated $E$. coli with cranberry juice of neutral $\mathrm{pH}$ changes the conformation of surface molecules on p-fimbriae within 2 hours profoundly and the adhesion power gets lost. ${ }^{17}$ The conclusion of cranberries as harboring potent anti-adhesive compounds other than fructose had fueled a lively research to identify them. ${ }^{18}$

Howsoever fascinating the exploration of these "gentle" anti-adhesive actions of cranberries are their clinical relevance is not self-evident. Cranberry constituents affect uropathogenic bacteria in more than one way and also disturb their cell integrity. Bacteria exposed to cranberry juice change their shape, ${ }^{6,19}$ and the development of p-fimbriae in E. coli is suppressed.

Proanthocyanidin (PAC)-standardized cranberry extracts inhibit bacterial growth and biofilm production of Staphylococcus epidermidis, Staphylococcus aureus, methicillin-resistant $S$. aureus, Staphylococcus saprophyticus, and E. coli. Extracts inhibit the growth of the Gram-positive bacteria (Staphylococcus spp.) with minimum inhibitory concentrations in the range of $0.02-5 \mathrm{mg} / \mathrm{mL}$ and inhibit biofilm production. In vitro studies have documented a pronounced effect on bacterial viability and the pathogenetic important production of biofilm by cranberry products. ${ }^{15,20}$

\section{A-type PAC in cranberry products have anti-adhesion activity in vitro}

In search for the anti-adhesive constituents in cranberries, a series of elegant experiments identified them as PACs. ${ }^{21-23}$ Cranberry PACs are polyphenolic flavanols of various lengths. Those PACs in cranberries with anti-adhesion quality are oligomers of catechin and epicatechin, also classified as condensed tannins. Their units are either linked through single $\mathrm{C}-\mathrm{C}$ bonds between $\mathrm{C}_{4}-\mathrm{C}_{8}$ and $\mathrm{C}_{4}-\mathrm{C}_{6}$ (B-type PACs) or through an additional ether-type bond between $\mathrm{C}_{2}-\mathrm{O}-\mathrm{C}_{7}$ and $\mathrm{C}_{2}-\mathrm{O}-\mathrm{C}_{5}$ (A-type PACs). PACs with at least one A-type linkage account for $50 \%-90 \%$ of PACs in cranberries. Only A-type PAC, restricted to cranberries and a few other plants, have the biological property of inhibiting in vitro adhesion of p-fimbriated E. coli to uroepithelial cells. B-type PAC is widely distributed in, eg, green tea, many fruits, or chocolate, but they lack anti-adhesive activity. ${ }^{23-25}$ When compared with other plants (eg, ananas, guava, and raisins) cranberries always had a superior anti-adhesion power, ${ }^{24-27}$ attributable to their A-type PAC content. ${ }^{21}$

Consecutively, the search for bioactive principles in cranberry products had focused on PAC and specifically A-type PAC. Low bioavailability of flavonoids has been of concern as they may limit or even hinder these compound's health effects. Unfortunately, there are very few data specifically on the bioavailability of A-type PAC. The bioavailability of cranberry anthocyans in general is low. In pharmacokinetic studies, B-type PAC had been poorly intestinally absorbed and had not reached the urinary tract intact. ${ }^{28}$ However, other studies suggest an excellent bioavailability of PAC. ${ }^{29-31}$

According to recent research, cranberries are not the only source of botanical anti-adhesion compounds. Berberis aristata and the goldenseal (Hydrastis canadensis), for example, owe their efficacy against infections to the alkaloide berberine. Berberine reduces the adhesion of uropathogenetic $E$. coli to the mucosa by suppressing the synthesis of fimbriae. ${ }^{32}$ Many more plants other than previously supposed harbor macromolecules with anti-adhesion properties. Such molecules are currently investigated for treatment of Helicobacter pylori-associated diseases. ${ }^{33-36}$

Currently, however, preventing UTI by anti-adhesion mechanisms is a concept brought forward only for cranberry products. This is reasonable, as there is strong evidence for cranberry-restricted A-type PAC as anti-adhesive compounds, sufficient evidence for PAC bioavailability in humans ${ }^{29-31}$ and the preservation of anti-adhesive activity in the urine after oral ingestion. ${ }^{14,16}$

Consequently, recently performed clinical trials have employed cranberry products standardized for their PAC, sometimes even for their A-type PAC content to deliver enough bioactivity to probands or patients. However, the ingested dose of PAC/A-type PAC necessary to inhibit bacterial adhesion in the urine is still unknown. There is no reliable bioassay to measure the appearance and activity of PAC in blood and urine. Some trials have tentatively incorporated serial measurements of anti-adhesion effects in the urine of patients to ensure bioactivity. ${ }^{14,38}$ Cranberry products 
administered in clinical trials had not been standardized either for PAC or for the crude PAC $\left(36 \mathrm{mg} /\right.$ day $\left.^{38,39}\right)$ or more sophisticatedly even for A-type PAC $\left(9.1 \mathrm{mg} / \mathrm{day}^{39-41}\right.$ or $18 \mathrm{mg} /$ day $^{42,43}$ ). In vitro study have suggested that $72 \mathrm{mg} /$ day PAC offers protection against bacterial adhesion in the bladder, ${ }^{30}$ others have recommended a daily dose of $36 \mathrm{mg}$ PAC. Thus, in most studies the cranberry products would have been underdosed.

PAC pharmacokinetics in humans had also to be considered. Anti-adhesion activity on bacteria is detectable 2 hours after oral intake of cranberry products, but disappears after 8 hours. ${ }^{6,14,16,26}$ Twice or more frequent daily intakes of cranberry products might be necessary to ensure an antiadhesive effect around the clock.

New data suggest that the content of bioactive PAC is not well controlled in many cranberry products and that its quantification is prone to error. When analyzing $19 \mathrm{com}-$ mercial cranberry products from the American and European markets for phenolic constituents and in vitro antioxidant capacity and uropathogenic bacterial anti-adhesion some products had been devoid of the relevant flavan-3-ols and some lacking anti-adhesion activity. ${ }^{44}$

Only 4/19 provided the recommended intake of $36 \mathrm{mg} \mathrm{PAC/day,} \mathrm{but} \mathrm{these} \mathrm{products} \mathrm{would} \mathrm{contain} \mathrm{as} \mathrm{low} \mathrm{as}$ 0-205 $\mu \mathrm{g} / \mathrm{g}$ A-type proanthocyanidine. Food processing to juice leads to substantial losses of phytochemicals, eg, of $>50 \%$ anthocyans. The more heat-stable PAC will also be degraded by the higher heat, necessary in processing into powders. Cell wall-bound PAC in cranberries is resistant to conventional methods of extraction - meaning that the content is usually underestimated. These cell wall-bound PACs are still bioaccessible in the human large intestine.

Another neglected variable is the botanical source of the "cranberry products". At least one trial with a positive result had not administered American cranberry (V. macrocarpon), but a mixed juice from the European cranberry (Vaccinium oxycoccus) and the lingonberry (Vaccinium vitis-idaea). ${ }^{45}$ New research, refuting older data, proved the putative active compounds to be almost absent in $V$. oxycoccus, but clearly present in lingonberry ( $V$. vitis-idaea). Thus, it might be as good to drink lingonberry juice instead of American cranberry juice. ${ }^{46}$

\section{The mixed evidence from clinical trials}

Patients potentially benefiting from cranberry prophylaxis range from young women troubled by frequent, but mild UTI over postmenopausal women with more severe recurrent UTI to children and adults with genito-urinary malformations or neurologic diseases suffering from almost permanent and complicated UTI. Within this range, patient's expectations about a prophylactic vary whether they are more or less severely plagued by UTI. Patients with co-morbidities at an increased risk for UTI complications desire a reliable cranberry product to safely replace established prophylactic regimes like antibiotics. For less ill patients, the convenience and attractivity of a natural product may have priority.

In each cohort, various cranberry-based regimens (juice, extracts, with or without PAC standardization, administered once, twice daily or more often, etc) have been studied vs no intervention, placebo, antibiotics, or other prophylactics (see Table 1). Pooled data from these studies have been re-evaluated in meta-analyses. The most recent two meta-analyses have come to different conclusions. While Jepson et $\mathrm{al}^{47}$ in their Cochrane Review concluded that there was no evidence for cranberries to prevent UTI, Wang et $\mathrm{al}^{14}$ found a weak evidence after having excluded one trial as a negative outlier. ${ }^{49}$ However, critics rightly argued that this maneuver had caused a bias, as data from a positive outlier study had still been analyzed. ${ }^{50}$

Investigators eager to explain negative outcomes of their trials had pointed to unexpectedly low UTI recurrence rates within the chosen observation periods and/or underdosing of the putative active principle. Several trials have indeed missed the calculated UTI recurrence rates necessary to show differences between groups. ${ }^{49,51,52}$ In one trial not a single event occurred. ${ }^{52}$ This problem should be overcome by recruiting patients with a true high recurrence risk indicated by a pattern of $>5 \mathrm{UTI} /$ year rather than on the basis of a recent UTI, as most trials up to now have done. How rewarding this might be is illustrated by a trial with a stratification of patients into a low- and high-risk group at randomization. ${ }^{42}$ Many more events occurred in the high-risk group unfolding a significant benefit for cranberry in the high-risk group, but not in the low-risk group.

Strengths and pitfalls of trials are best exemplified by those performed in otherwise healthy young women. UTI in these patients is often related to sexual activity, rarely progressing to pyelonephritis, but nonetheless troubling. Behavioral measures are effective to reduce UTI in this cohort, but cranberry products could be a useful adjunct.

A much cited Finnish trial had impressed with a reduction of the cumulative rate of the first recurrence of UTI by $56 \%$ when the young women had drunken $50 \mathrm{~mL}$ European cranberry-lingonberry concentrate daily for 6 months. ${ }^{45}$ Infection rates had remained lower for 1 year, albeit the juice had only been available for the first 6 months. 

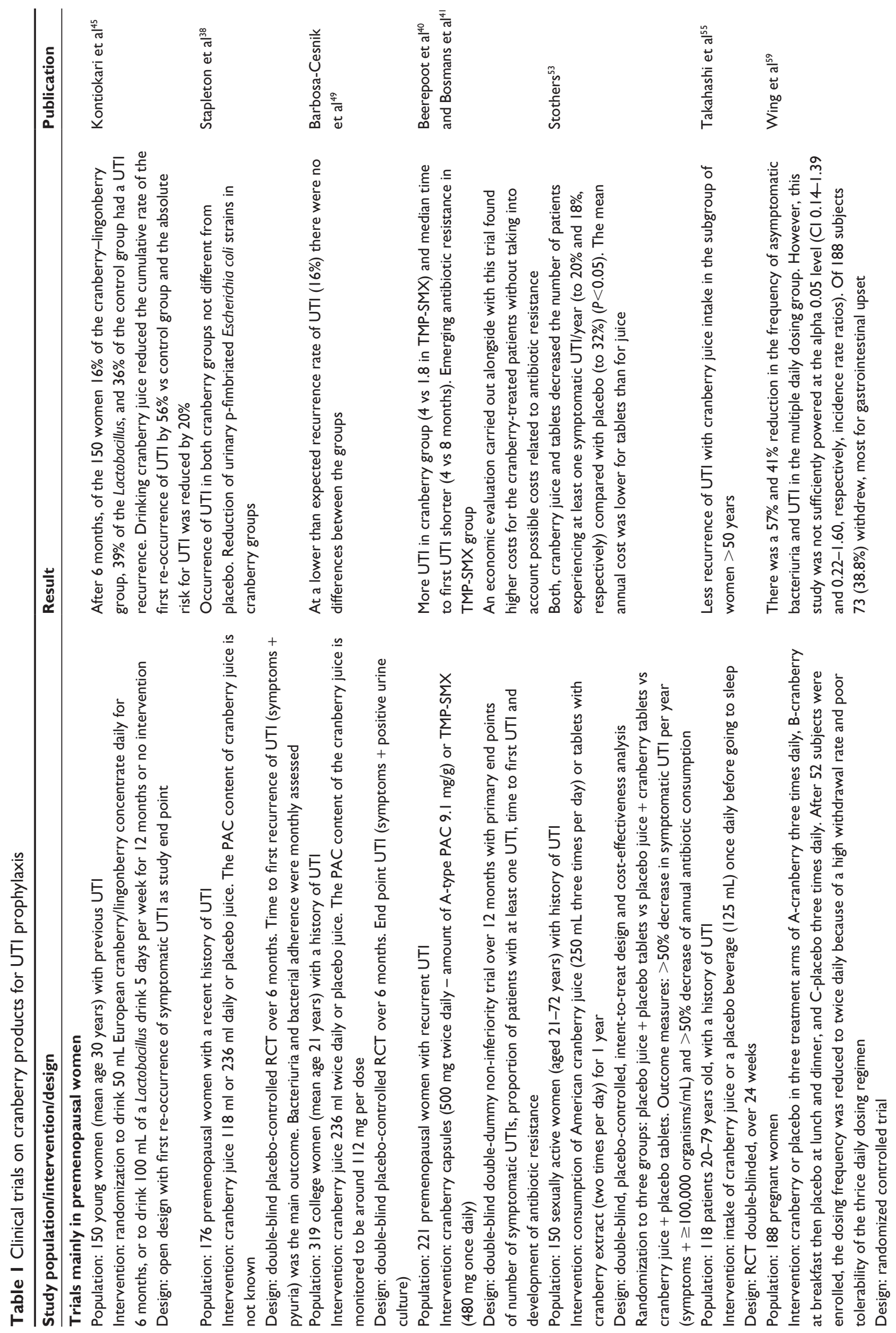

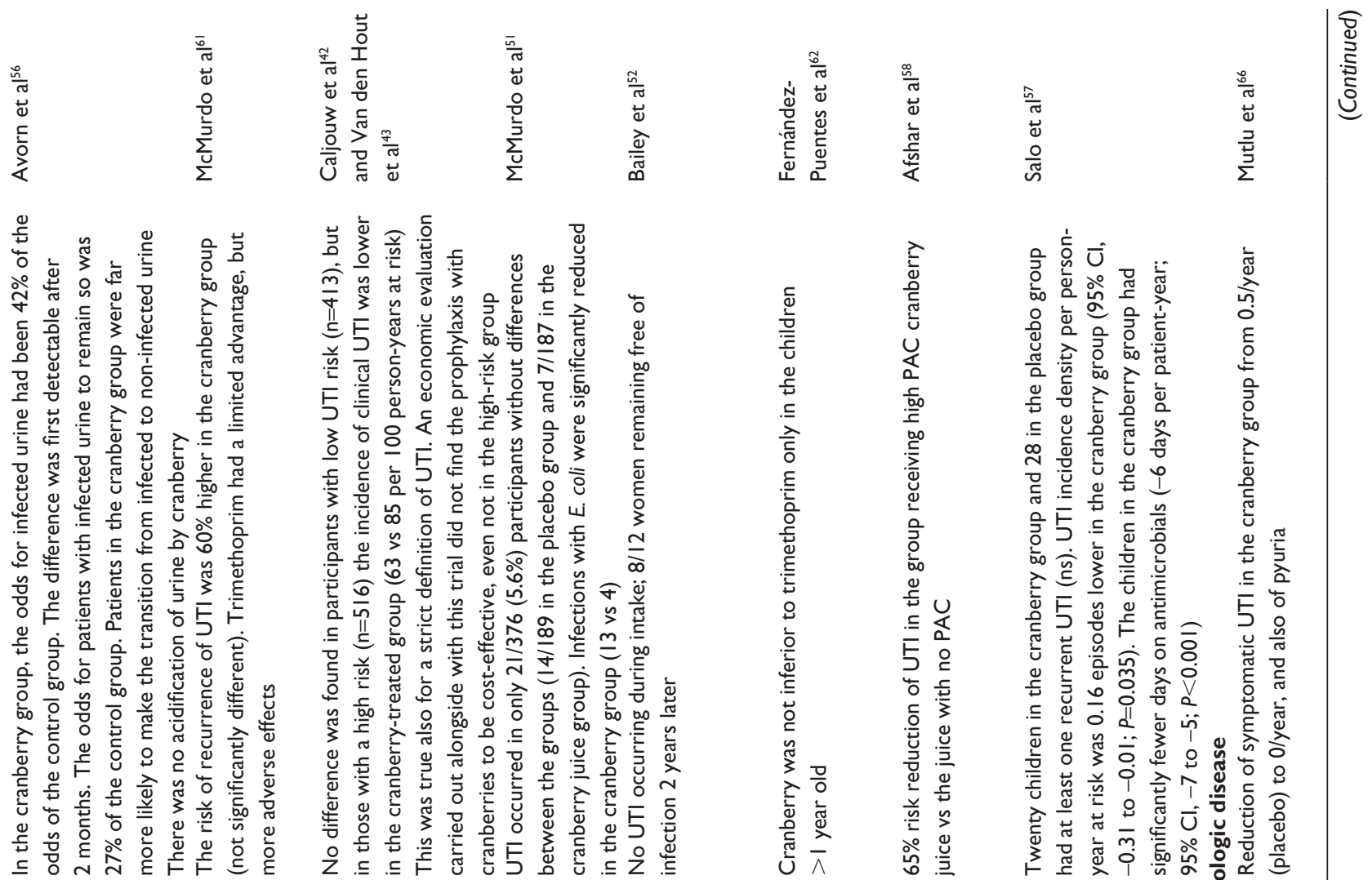

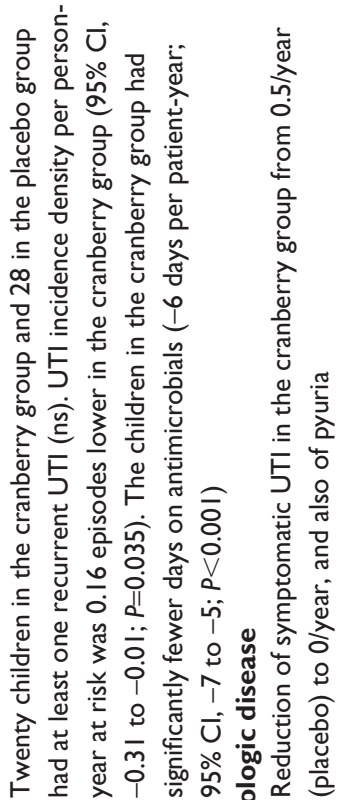
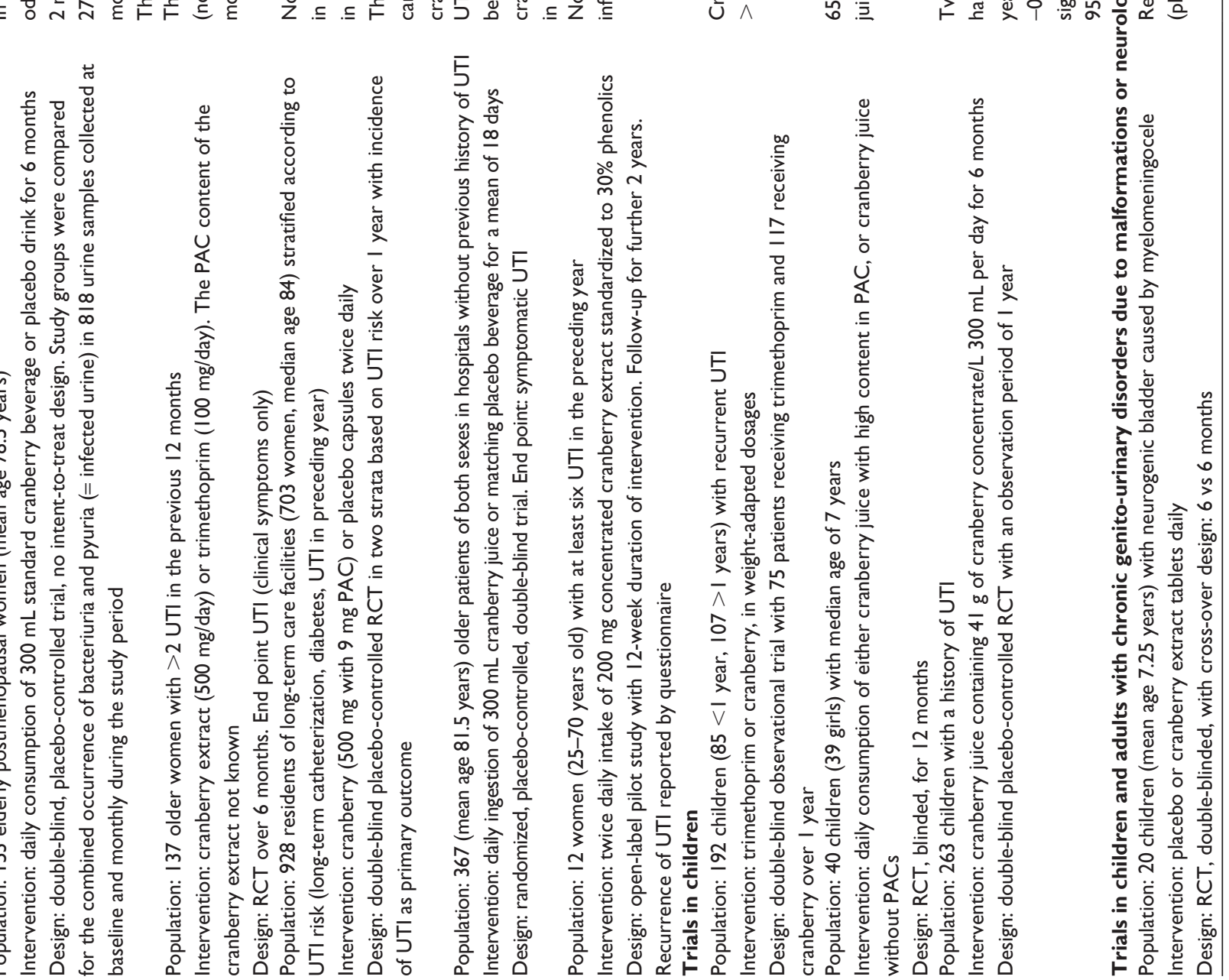


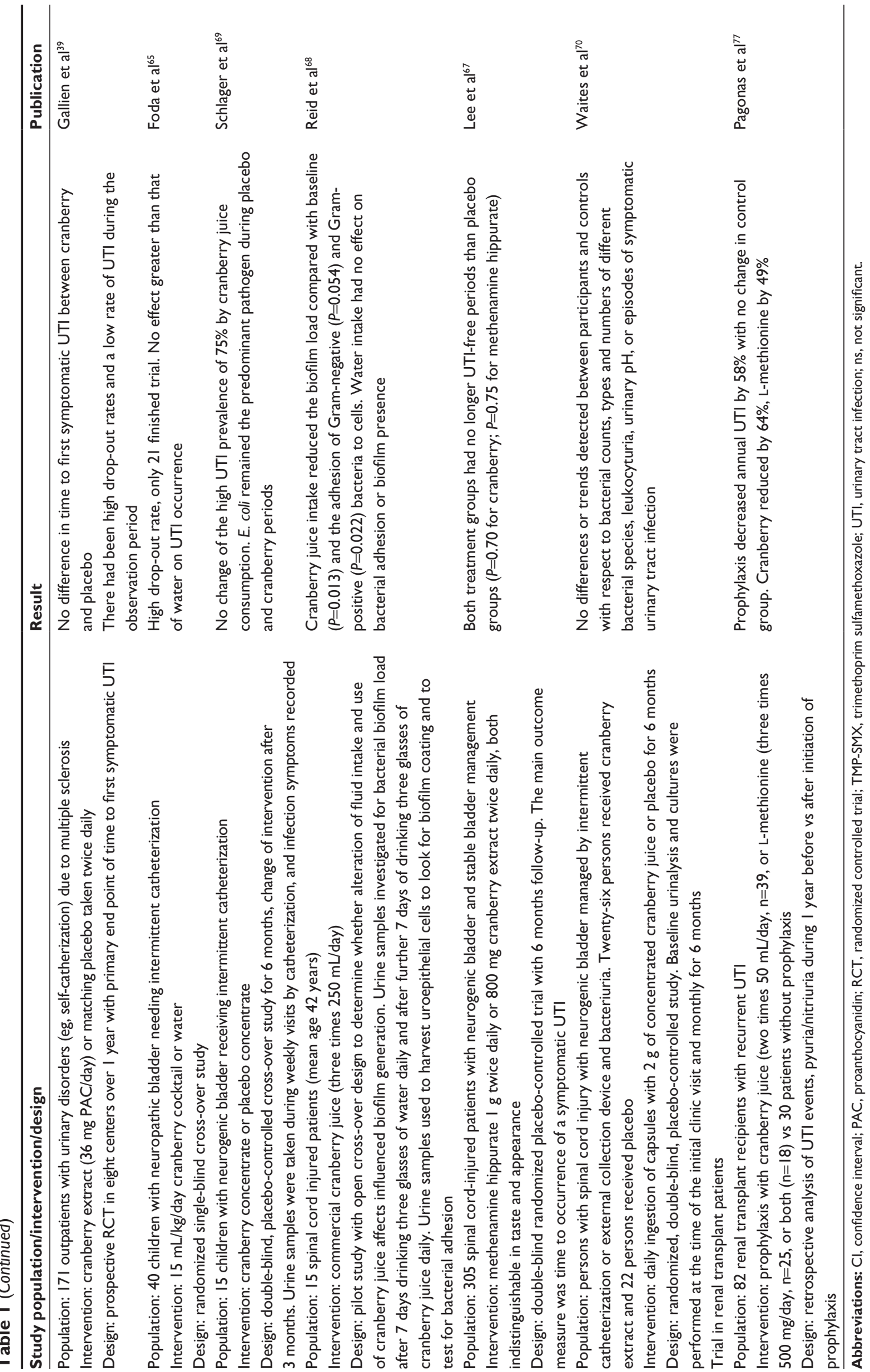


In a Canadian study, cranberry juice $(250 \mathrm{~mL}$ three times daily) and cranberry extract in tablets (taken twice daily) had likewise reduced UTI in 150 sexually active women. ${ }^{53}$ Contrastingly, the trial by Barbosa-Cesnik et a ${ }^{49}$ among collegeaged women had failed to find a benefit for a PAC-standardized cranberry juice. Less than expected UTI had occurred during the observation time of 6 months and ascorbic acid in the placebo drink had possibly conferred protection on the control group. In fact, ascorbic acid has an uncertain efficacy in UTI. It is frequently discussed in reviews on UTI, but there is only one trial showing a positive effect in pregnant women. ${ }^{54}$

In the two trials with positive outcomes, high enough UTI recurrence rates had disclosed a benefit for cranberry products within 12 months. Cranberry products of sufficient bioactivity had apparently been chosen and administered at an effective dosing schedule. A high delivery of cranberry bioactivity had been ensured in the Canadian study by three high volume servings of juice or two cranberry tablets daily, while only a once daily serving of $8 \mathrm{oz}(=236 \mathrm{~mL})$ cranberry juice had been consumed by patients in the negative trial. The Canadian prescription had obviously been guided by in vitro data on the quickly disappearing anti-adhesion effects of A-type PAC. The success in the Finnish trial can only be explained by a unique quality of the administered juice concentrate. As it reduced UTI recurrence beyond the time of actual exposure, it might have had a longer-lasting influence on bacterial colonization in addition to the shortlived anti-adhesion effect. The juice concentrate made from European cranberries and lingonberries somehow challenges the status of the American cranberry as only botanical UTI prophylactic to work by an anti-adhesion mechanism.

Underdosing, short observation times, and inappropriate selection of patients have all the same accounted for disappointing results of trials performed in elderly postmenopausal women. ${ }^{51,53,55,56}$

To give an example, only 21/376 (5.6\%) of hospitalized patients (mean age 81.5 years) had a clinical UTI within a follow-up of 35 days and an intervention period of 18 days in the study by McMurdo et al..$^{51}$ At that low event rate, the study time had been too short to find differences, which may well have become evident at a longer study duration. The risk of underdosing has led investigators to apply different doses of cranberry products ${ }^{38,57-59}$ or to simply administer the highest available cranberry dose. ${ }^{60}$ Wing et a ${ }^{59}$ observed a trend toward fewer UTIs in women given higher doses of cranberry juice vs those who received placebo.

There is an imperative demand to establish an optimal in vivo dosage of cranberry products and ongoing studies to determine dose are currently under way. ${ }^{37}$ At the same time, investigators are confronted with a surprisingly low acceptability of cranberry products, especially of those with higher PAC contents. Patients had refused taking higher dosages in studies with a dose-finding intention. ${ }^{37}$ Withdrawal rates have generally been quite high (up to 55\%) in studies, suggesting that cranberry products may not be acceptable over long periods. Complaints about gastrointestinal upset are familiar and explainable from the astringency of higher dosed PAC. In trying to improve palatability of cranberry products, they have often been heavily sweetened with the disadvantage of a high calorie intake and weight gain in patients.

As it is inconvenient taking cranberry products two to three times daily for prolonged periods of time, strong arguments are needed to convince patients to rely on them. Patients will otherwise carry on with drugs like antibiotics and prophylactics, which they often also dislike, but feel safe with. Long-term antibiotics like trimethoprim are an effective way to prevent UTI and three trials have studied cranberry products in head-to-head comparisons with them. ${ }^{40,61,62}$ In two trials, more UTI had occurred in the cranberry-treated patients than in antibiotic-treated patients..$^{40,61}$ In defend of the failure, underdosing of cranberry bioactivity had been discussed also for these studies. Moreover, the documented rise of antibiotic resistance in the antibiotic-treated patients may have a negative impact on treatment costs in the long run. ${ }^{41}$ Cranberry products have the reputation of not driving antibiotic resistance. In a third small trial performed in children, cranberry had not been inferior to trimethoprim. ${ }^{62}$

Another widely discussed advantage of cranberry products over antibiotics is their anti-biofilm efficacy, which had been documented in vitro. ${ }^{63,64}$ Biofilms are breeding grounds for bacteria, including multi-resistant strains, and a source for recurrent UTI, eg, in patients with neuropathic bladder dysfunction with indwelling catheters. Unfortunately, studies in this group of patients had controversial outcomes not really encouraging the use of cranberry products. ${ }^{65-71}$

At least three studies have addressed the cost-effectiveness of cranberry products for UTI prophylaxis in association with clinical trials. When taking into account the achieved reduction of spent antibiotics, both tablets of cranberry extract and juice have been found to be cost-effective with a superiority of the tablets in one trial. ${ }^{32}$ When compared with trimethoprim sulfamethoxazole, cranberry prophylaxis in premenopausal women had not been cost-effective. ${ }^{41}$ However, the potential financial impacts of the observed increased antibiotic resistances in trimethoprim sulfamethoxazole-treated patients had not been taken into account. Even in a trial with a benefit 
in patient with high UTI risks, cranberry prophylaxis had not been likely to be cost-effective in the investigated dose, frequency, and setting. ${ }^{43}$ The high costs are caused by the recommended uninterrupted daily or even twice daily intake of available cranberry products for prolonged periods of time.

Besides the problems with palatability there are no major safety concerns about cranberry products. In adults, even high amounts of cranberry juice appear to be non-toxic. Infants and young children should restrict the consumption to moderate quantities since they may suffer from gastrointestinal distress and diarrhea. The safety of cranberry products in pregnancy and lactation has been assessed as excellent. ${ }^{72}$ More serious adverse effects of cranberry products like drug-cranberry interactions (due to the inhibitory effect of flavonoids on cytochrome P450-mediated drug metabolism) have been reported, but their relevance is questionable. An unreasonable high intake of cranberry juice had caused bleeding in patients treated with warfarin. ${ }^{73}$ Beyond this case report an interaction risk with warfarin or other drugs metabolized by cytochrome P450 enzymes had not been confirmed. ${ }^{74}$ Cranberry juice had no negative impact on cyclosporin pharmacokinetics in volunteers and in a small retrospective trial in renal transplant patients cranberry products had reduced troublesome UTI without causing safety problems. ${ }^{75-77}$ There had been a debate on whether cranberry products were safe in patients with a history of nephrolithiasis, but a relevant pro-lithogenic risk had not been confirmed. ${ }^{78-80}$

\section{Conclusion}

The evidence to use cranberry products as an UTI prophylactic is generally regarded as inconclusive. ${ }^{81,82}$ According to recent meta-analyses, overall UTI recurrence rates over 1 year could not be reduced by various cranberry products. This is also true for the following separately evaluated subgroups: elderly, pediatric patients, patients with neurogenic bladder, and patients with chronic indwelling urinary catheters.

Cranberry products inhibit bacterial adhesion in biologically relevant models and there is reason to assume that the anti-adhesive quality is specifically attributable to A-type PAC within the anthocyanidin/PAC moieties. This makes it plausible to administer cranberry products rich in anti-adhesive A-type PAC, although it remains uncertain whether clinical outcomes rely on the anti-adhesion effect alone. Further putative effects are related to larger cranberry oligomeric polyphenols with an influence on gut microbiota, but this has not been investigated so far.

By following the currently best hypothesis on how cranberry products may prevent UTI, products should be standardized for a high amount of anti-adhesive A-type PAC. Analytic problems related to measuring the A-type PAC content and their bioavailability in cranberry products need to be overcome to allow comparisons of products, to extrapolate study results, and to establish reliable dosing schemes. Efforts should be made to improve the palatability of cranberry products and to alleviate the inconveniences of current dosing schedules.

\section{Disclosure}

The authors report no conflicts of interest in this work.

\section{References}

1. Bodel PT, Cotran R, Kass EH. Cranberry juice and the antibacterial action of hippuric acid. J Lab Clin Med. 1959;54:881-888.

2. McLeod DC, Nahata MC. Methenamine therapy and urine acidification with ascorbic acid and cranberry juice. Am J Hosp Pharm. 1978; 35(6):654

3. Blatherwick NR, Long ML. Studies on urinary acid II. The increased acidity produced by eating prunes and cranberries. $J$ Biol Chem. 1923;57:815-818.

4. Monroy-Torres R, Macias AE. [Does cranberry juice have bacteriostatic activity?]. Rev Invest Clin. 2005;57(3):442-446. Spanish.

5. Leitão DP, Polizella AC, Ito IY, Spadaro AC. Antibacterial screening of anthocyanic and proanthocyanic fractions from cranberry juice. J Med Food. 2005;8(1):36-40.

6. Sobota AE. Inhibition of bacterial adherence by cranberry juice: potential use for the treatment of urinary tract infections. J Urol. 1984;131:1013.

7. Schmidt DR, Sobota AE. An examination of the anti-adherence activity of cranberry juice on urinary and non-urinary bacterial isolates. Microbios. 1988;55:173-181.

8. Johnson JR, Kaster N, Kuskowski MA, Ling GV. Identification of urovirulence traits in Escherichia coli by comparison of urinary and rectal E. coli isolates from dogs with urinary tract infection. $J$ Clin Microbiol. 2003;41(1):337-345.

9. Gupta K, Chou MY, Howell A, Wobbe C, Grady R, Stapleton AE. Cranberry products inhibit adherence of p-fimbriated Escherichia coli to primary cultured bladder and vaginal epithelial cells. J Urol. 2007; 77(6):2357-2360.

10. Salminen A, Loimaranta V, Joosten JA, et al. Inhibition of P-fimbriated Escherichia coli adhesion by multivalent galabiose derivatives studied by a live-bacteria application of surface plasmon resonance. J Antimicrob Chemother. 2007;60(3):495-501.

11. Rice JC, Peng T, Spence JS, et al. Pyelonephritic Escherichia coli expressing $\mathrm{p}$-fimbriae decrease immune response of the mouse kidney. J Am Soc Nephrol. 2005;16:3583-3591.

12. Lavigne JP, Bourg G, Combescure C, Botto H, Sotto A. In-vitro and in-vivo evidence of dose-dependent decrease of uropathogenic Escherichia coli virulence after consumption of commercial Vaccinium macrocarpon (cranberry) capsules. Clin Microbiol Infect. 2008;14(4):350-355.

13. Howell AB, Vorsa N, Der Marderosian A, Foo LY. Inhibition of the adherence of p-fimbriated Escherichia coli to uroepithelial cell surfaces by proanthocyanidin extracts from cranberries. $N$ Eng $J$ Med. 1998;339:1085.

14. Tao Y, Pinzón-Arango PA, Howell AB, Camesano TA. Oral consumption of cranberry juice cocktail inhibits molecular scale adhesion of clinical uropathogenic Escherichia coli. J Med Food. 2011;14(7/8):739-745.

15. LaPlante KL, Sarkision SA, Woodmansee S, Rowley DC, Seeram NP. Effects of cranberry extracts on growth and biofilm production of Escherichia coli and Staphylococcus species. Phytother Res. 2012;26(9): 1371-1374. 
16. DiMartino P, Agniel R, David K, et al. Reduction of Escherichia coli adherence to uroepithelial bladder cells after consumption of cranberry juice: a double-blind randomized placebo-controlled crossover trial. World J Urol. 2006;24(1):21-27.

17. Liu Y, Black MA, Caron L, Camesano TA. Role of cranberry juice on molecular-scale surface characteristics and adhesion behaviour of Escherichia coli. Biotechnol Bioeng. 2006;93(2):297-305.

18. Zafriri D, Ofek I, Adar R, Pocino M, Sharon N. Inhibitory activity of cranberry juice on adherence of type 1 and type $\mathrm{P}$ fimbriated Escherichia coli to eucaryotic cells. Antimicrob Agents Chemother. 1989;33: 92-98.

19. Ahuja S, Kaack B, Roberts J. Loss of fimbrial adhesion with the addition of Vaccinium macrocarpon to the growth medium of p-fimbriated E. coli. J Urol. 1998;159:559-562.

20. Rabe HS, Bernardo SM, Howell AB, Lee SA. Cranberry-derived proanthocyanidins prevent formation of Candida albicans biofilms in artificial urine through biofilm- and adherence-specific mechanisms. J Antimicrob Chemother. 2014;69(2):428-436.

21. Foo LY, Lu Y, Howell AB, Vorsa N. A-type proanthocyanidin trimers from cranberry that inhibit adherence of uropathogenic p-fimbriated E. coli. J Nat Prod. 2000;63(9):1225-1228.

22. Foo LY, Lu Y, Howell AB, Vorsa N. The structure of cranberry proanthocyanidins which inhibit adherence of uropathogenic P-fimbriated Escherichia coli in vitro. Phytochemistry. 2000;54:173-181.

23. Howell AB, Reed JD, Krueger CG, Winterbottom R, Cunningham DG, Leahy M. A-type cranberry proanthocyanidins and uropathogenic bacterial anti-adhesion activity. Phytochemistry. 2005;66(18):2281-2291.

24. Ofek I, Goldhar J, Zafriri D, Lis H, Adar R, Sharon N. Anti-Escherichia coli adhesin activity of cranberry and blueberry juices. $N$ Engl J Med. 1991;324:1599.

25. Ofek I, Goldhar J, Sharon N. Anti-Escherichia coli adhesin activity of cranberry and blueberry juices. Adv Exp Med Biol. 1996;408:179-183.

26. Greenberg JA, Newmann SJ, Howell AB. Consumption of sweetened dried cranberries versus unsweetened raisins for inhibition of uropathogenic Escherichia coli adhesion in human urine: a pilot study. J Altern Complement Med. 2005;11(5):875-878.

27. Johnson-White B, Buquo L, Zainali M, Ligler FS. Prevention of nonspecific bacterial cell adhesion in immunoassays by use of cranberry juice. Anal Chem. 2006;78(3):853-857.

28. Turner A, Chen S-N, Nikolic D, van Breemen R, Farnsworth NR, Pauli GF. Coumaroyl iridoids and a depside from cranberry (Vaccinium macrocarpon). J Nat Prod. 2007;70:253-258.

29. Harmand MF, Blanquet P. The fate of total flavonoid oligomers (OFT) extracted from 'VITIS VINFERAL' in the rat. Eur J Drug Metab Pharmacokinet. 1978;1:15-30.

30. Howell AB, Botto H, Combescure C, et al. Dosage effect on uropathogenic Escherichia coli anti-adhesion activity in urine following consumption of cranberry powder standardized for proanthocyanidin content: a multicentric randomized double blind study. BMC Infect Dis. 2010;10:94.

31. Habash MB, van der Mei HC, Busscher HJ, Reid G. The effect of water, ascorbic acid, and cranberry derived supplementation on human urine and uropathogen adhesion to silicone rubber. Can J Microbiol. 1999;45: 1189-1193.

32. Sun D, Abraham SN, Beachey EH. Influence of berberine sulfate on synthesis and expression of Pap fimbrial adhesin in uropathogenic Escherichia coli. Antimicrob Agents Chemother. 1988;32(8):1274-1277.

33. Wittschier N, Faller G, Hensel A. An extract of Pelargonium sidoides (EPs 7630) inhibits in situ adhesion of Helicobacter pylori to human stomach. Phytomedicine. 2007;14(4):285-288.

34. Lengsfeld C, Deters A, Faller G, Hensel A. High molecular weight polysaccharides from black currant seeds inhibit adhesion of Helicobacter pylori to human gastric mucosa. Planta Med. 2004;70(7):620-626.

35. Marcial G, Sendker J, Brandt S, et al. Gastroprotection as an example: antiadhesion against Helicobacter pylori, anti-inflammatory and antioxidant activities of aqueous extracts from the aerial parts of Lippia integrifolia Hieron. J Ethnopharmacol. 2014;155(2):1125-1133.
36. Messing J, Niehues M, Shevtsova A, Borén T, Hensel A. Antiadhesive properties of arabinogalactan protein from ribes nigrum seeds against bacterial adhesion of Helicobacter pylori. Molecules. 2014;19(3): 3696-3671.

37. Stothers L. Effects of cranberry-containing products in women with recurrent urinary tract infections (UTIs). 2008. Available from: http://www. clinicaltrialsfeeds.org/clinical-trials/show/NCT00100061. ClinicalTrials. gov Identifier: NCT00100061. Accessed February 8, 2015.

38. Stapleton AE, Dziura J, Hooton TM, et al. Recurrent urinary tract infection and urinary Escherichia coli in women ingesting cranberry juice daily: a randomized controlled trial. Mayo Clin Proc. 2012;87(2):143-150.

39. Gallien P, Amarenco G, Benoit N, et al. Cranberry versus placebo in the prevention of urinary infections in multiple sclerosis: a multicenter, randomized, placebo-controlled, double-blind trial. Mult Scler. 2014;20(9):1252-1259.

40. Beerepoot MA, ter Riet G, Nys S, et al. Cranberries vs antibiotics to prevent urinary tract infections: a randomized double-blind noninferiority trial in premenopausal women. Arch Intern Med. 2011;171(14):1270-1278.

41. Bosmans JE, Beerepoot MAJ, Prins JM, Riet ter G, Geerlings SE. Cost-effectiveness of cranberries vs antibiotics to prevent urinary tract infections in premenopausal women: a randomized clinical trial. PLoS One. 2014;9(4):e91939.

42. Caljouw MAA, van den Hout WB, Putter H, Achterberg WP, Cools HJM, Gussekloo J. Effectiveness of cranberry capsules to prevent urinary tract infections in vulnerable older persons: a double-blind randomized placebo-controlled trial in long-term care facilities. J Am Geriat Soc. 2014;62:103-110.

43. Van den Hout WB, Caljouw MA, Putter H, Cools HJ, Gussekloo J. Costeffectiveness of cranberry capsules to prevent urinary tract infection in long-term care facilities: economic evaluation with a randomized controlled trial. J Am Geriatr Soc. 2014;62(1):111-116.

44. Sánchez-Patán F, Bartolomé B, Martin-Alvarez PJ, Anderson M, Howell A, Monagas M. Comprehensive assessment of the quality of commercial cranberry products. Phenolic characterization and in vitro bioactivity. J Agric Food Chem. 2012;60(13):3396-3408.

45. Kontiokari T, Sundquist K, Nuutinen M, Pokka T, Koskela M, Uhari M. Randomised trial of cranberry-lingonberry juice und Lactobacillus GG drink for the prevention of urinary tract infections in women. BMJ. 2001; 322(7302):1571.

46. Blumberg JB, Camesano TA, Cassidy A, et al. Cranberries and their bioactive constituents in human health. Adv Nutr. 2013;4:618-632.

47. Jepson RG, Williams G, Craig JC. Cranberries for preventing urinary tract infections. Cochrane Database Syst Rev. 2012;10:CD001321.

48. Wang $\mathrm{CH}$, Fang CC, Chen NC, et al. Cranberry-containing products for prevention of urinary tract infections in susceptible populations: a systematic review and meta-analysis of randomized controlled trials. Arch Intern Med. 2012;172(13):988-996.

49. Barbosa-Cesnik C, Brown MB, Buxton M, Zhang L, DeBusscher J, Foxman B. Cranberry juice fails to prevent recurrent urinary tract infection: results from a randomized placebo-controlled trial. Clin Infect Dis. 2011;52(1):23-30.

50. Allan GM, Nicolle L. Cranberry for preventing urinary tract infection. Can Fam Physician. 2013;59(4):367.

51. McMurdo MCT, Bissett L, Rosemary J, Price G, Phillips G, Crombie IK. Does ingestion of cranberry juice reduce symptomatic urinary tract infections in older people in hospital? Age Ageing. 2005;34:256-261.

52. Bailey DT, Dalton C, Joseph Daugherty F, Tempesta MS. Can a concentrated cranberry extract prevent recurrent urinary tract infections in women? A pilot study. Phytomedicine. 2007;14(4):237-241.

53. Stothers L. A randomized trial to evaluate effectiveness and cost effectiveness of naturopathic cranberry products as prophylaxis against urinary tract infection in women. Can J Urol. 2002;9(3):1558-1562.

54. Ochoa-Brust GJ, Fernández AR, Villanueva-Ruiz GJ, Velasco R, Trujillo-Hernández B, Vásquez C. Daily intake of $100 \mathrm{mg}$ ascorbic acid as urinary tract infection prophylactic agent during pregnancy. Acta Obstet Gynecol Scand. 2007;86(7):783-787. 
55. Takahashi S, Hamasuna R, Yasuda M, et al. A randomized clinical trial to evaluate the preventive effect of cranberry juice (UR65) for patients with recurrent urinary tract infection. J Infect Chemother. 2013;19(1): $112-117$.

56. Avorn J, Monane M, Gurwitz JH, Glynn RJ, Choodnovsky I, Lipsitz LA. Reduction of bacteriuria and pyuria after ingestion of cranberry juice. JAMA. 1994;271:751-754.

57. Salo J, Uhari M, Melminen M, et al. Cranberry juice for the prevention of recurrences of urinary tract infections in children: a randomized placebo-controlled trial. Clin Infect Dis. 2012;54(3):340-346.

58. Afshar K, Stothers L, Scott H, MacNeily AE. Cranberry juice for the prevention of pediatric urinary tract infection: a randomized control trial. J Urol. 2012;188(4 Suppl):1584-1587.

59. Wing DA, Rumney PJ, Preslicka CW, Chung JH. Daily cranberry juice for the prevention of asymptomatic bacteriuria in pregnancy: a randomized, controlled pilot study. J Urol. 2008;180(4):1367-1372.

60. McGuinness SD, Krone R, Metz LM. A double-blind, randomized, placebo-controlled trial of cranberry supplements in multiple sclerosis. J Neurosci Nurs. 2002;34:4-7.

61. McMurdo ME, Argo I, Phillips G, Daly F, Davey P. Cranberry or trimethoprim for the prevention of recurrent urinary tract infections? A randomized controlled trial in older women. JAntimicrob Chemother. 2009;63(2):389-395.

62. Fernández-Puentes V, Uberos J, Rodriguez-Belmonte R, et al. Efficacy and safety profile of cranberry in infants and children with recurrent urinary tract infection. An Pediatr (Barc). Epub October 6, 2014.

63. Morris NS, Stickler DJ. Does drinking cranberry juice produce urine inhibitory to the development of crystalline, catheter-blocking Proteus mirabilis biofilms. BJU Int. 2001;88(3):192-197.

64. Ulrey RK, Barksdale SM, Zhou W, van Hoek ML. Cranberry proanthocyanidins have anti-biofilm properties against Pseudomonas aeruginosa. BMC Complement Altern Med. 2014;14(1):499.

65. Foda MM, Middlebrook PF, Gatfield CT, Potvin G, Wells G, Schillinger JF. Efficacy of cranberry in prevention of urinary tract infection in a susceptible pediatric population. Can J Urol. 1995;2(1):98-102.

66. Mutlu H, Ekinci Z. Urinary tract infection prophylaxis in children with neurogenic bladder with cranberry capsules: randomized controlled trial. ISRN Pediatr. 2012;2012:317280.

67. Lee BB, Haran MJ, Hunt LM, et al. Spinal-injured neuropathic bladder antisepsis (SINBA) trial. Spinal Cord. 2007;45(8):542-550.

68. Reid G, Hsiehl J, Potter P, et al. Cranberry juice consumption may reduce biofilms on uroepithelial cells: pilot study in spinal cord injured patients. Spinal Cord. 2001;39:26-30.

69. Schlager TA, Anderson S, Trudell J, Hendley JO. Effect of cranberry juice on bacteriuria in children with neurogenic bladder receiving intermittent catheterization. J Pediatr. 1999;135(6):698-702.
70. Waites KB, Canupp KC, Armstrong S, De Vivo MJ. Effect of cranberry extract on bacteriuria and pyuria in persons with neurogenic bladder secondary to spinal cord injury. J Spinal Cord Med. 2004;27(1): $35-40$.

71. Ferrara P, Romaniello L, Vitelli O, Gatto A, Serva M, Cataldi L. Cranberry juice for the prevention of recurrent urinary tract infections: a randomized controlled trial in children. Scand J Urol Nephrol. 2009; 43(5):369-372.

72. Dugoua JJ, Seely D, Perri D, Mills E, Koren G. Safety and efficacy of cranberry (Vaccinium macrocarpon) during pregnancy and lactation. Can J Clin Pharmacol. 2008;15(1):e80-e86.

73. Rindone JP, Murphy TW. Warfarin-cranberry juice interaction resulting in profound hypoprothrombinemia and bleeding. Am JTher. 2006;13(3): 283-284.

74. Li Z, Seeram NP, Carpenter CL, Thames G, Minutti C, Bowerman S. Cranberry does not affect prothrombin time in male subjects on warfarin. J Am Diet Assoc. 2006;106(12):2057-2061.

75. Grenier J, Fradette C, Morelli G, Merritt GJ, Vranderick M, Ducharme MP. Pomelo juice, but not cranberry juice, affects the pharmacokinetics of cyclosporine in humans. Clin Pharmacol Ther. 2006;79(3):255-262.

76. Srinivas NR. Cranberry juice ingestion and clinical drug-drug interaction potentials; review of case studies and perspectives. J Pharm Pharm Sci. 2013;16(2):289-303.

77. Pagonas N, Hörstrup J, Schmidt D, et al. Prophylaxis of recurrent urinary tract infection after renal transplantation by cranberry juice and L-methionine. Transplant Proc. 2012;44(10):3017-3021.

78. McHarg T, Rodgers A, Charlton K. Influence of cranberry juice on the urinary risk factors for calcium oxalate kidney stone formation. $B J U$ Int. 2003;92(7):765-768.

79. Terris MK, Issa MM, Tacker JR. Dietary supplementation with cranberry concentrate tablets may increase the risk of nephrolithiasis. Urology. 2001;57(1):26-29.

80. Gettman MT, Ogan K, Brinkley LJ, Adams-Huet B, Pak CY, Pearle MS. Effect of cranberry juice consumption on urinary stone risk factors. J Urol. 2005;174(2):590-594.

81. Vasileiou I, Katsargyris A, Theocharis S, Giaginis C. Current clinical status on the preventive effects of cranberry consumption against urinary tract infections. Nutr Res. 2013;33(8):595-607.

82. Micali S, Isgro G, Bianchi G, Miceli N, Calapai G, Navarra M. Cranberry and recurrent cystitis: more than marketing? Crit Rev Food Sci Nutr. 2014;54(8):1063-1075.
Botanics: Targets and Therapy

\section{Publish your work in this journal}

Botanics: Targets and Therapy is an international, peer-reviewed, open access journal focusing on the discovery and development of active compounds based upon or found naturally occurring in the plant kingdom that may have therapeutic potential in any disease state. The manuscript management system is completely online and includes a very

\section{Dovepress}

quick and fair peer-review system. Visit http://www.dovepress.com/ testimonials.php to read real quotes from published authors. 